\title{
Determination of the Geochemical Weathering Indices and Trace Elements Content of New Volcanic Ash Deposits from Mt. Talang (West Sumatra) Indonesia
}

\begin{abstract}
Since the Indonesian archipelago is part of the very active and dynamic Pacific Ring of Fires, the volcanic eruptions occur from time to time. Immediately after the eruption of Mount Talang in West Sumatra (April 12, 2005), volcanic ashes, both unleached and leached were collected. The deposits from Mt. Talang were andesitic to basaltic in composition. The volcanic ash consisted of volcanic glass, plagioclase feldspar in various proportions, orthopyroxene, clinopyroxene, olivine, amphibole, titanomagnetite. We conducted the total elemental analysis of the bulk samples of the volcanic ash. The contents of major, trace and rare elements as well as heavy metals were determined by wet chemical methods and xray fluorescence (XRF) analyses. Although the volcanic ash of Mt. Talang are still very new, an evaluation of the geochemical weathering indi ces was performed with the objective of showing the volcanic ash condition at the early stage of weathering. Eight weathering indices were evaluated. The results showed that the unleached volcanic ash has higher Rux ton Ratio (R), Weathering Index of Parker (WIP), Product of Weathering Index (PWI) and Silica Titanium Index (STI) values compared to the leached ash, while the leached ash exhibited higher Chemical Index of Alteration (CIA), Chemical Index of Weathering (CIW), Vogt's Residual Index (VO), and Plagioclase Index of Alteration (PIA). These weathering indices can be used to quantify the condition of the volcanic ashes at the initial stage of weathering, to evaluate their fertility, to provide a better understanding of element mobility during weathering, and predict the source of soil nutrients as well as determine the products of primary min erals alteration.
\end{abstract}

